\title{
The Characterization of the Resin Bonded Graphite Composite Bipolar Plate using Isotropic Graphite Powder for PEM Fuel Cell
}

\author{
Kwang Youn Cho ${ }^{1, \uparrow}$, Doh Hyung Riu ${ }^{1}$, Seung Hun Hui ${ }^{1}$, Hong Suk Kim², \\ Yoon Jung Chung and Yun Soo Lim $^{3}$ \\ ${ }^{1}$ Division of Nano Materials Application, KICET, Kumchen-gu, Seoul 153-801, Korea \\ ${ }^{2}$ LG Micron Ltd, LG Material \& Parts R\&D Center, 1271, Sangrog-gu, Ansan-city, Gyeonggi-do, 426-822, Korea \\ ${ }^{3}$ Department of New Materials Engineering, Myongji Univ. Cheoin-gu, Yongin-city, Kyunggido 449-728, Korea \\ "e-mail: \\ (Received October 10, 2007; Accepted December 5, 2007)
}

\begin{abstract}
In this study, graphite composites were fabricated by warm press molding method to realize commercialization of PEM fuel cells. Graphite composites have been considered as alternative economic materials for bipolar plate of PEM fuel cells. Graphite powder that enables to provide electrical conductivity was selected as the main substance. The graphite powder was mixed with phenolic resin and the mixture was pressed using a warm press method.

First of all, the graphite powder was pulverized with a ball mill for the dense packing of composite. As the ball milling time increases, the average size of particles decreases and the size distribution becomes narrow. This allows for improvement of the uniformity of graphite composite. However, the surface electrical resistivity of graphite composite increases as the ball milling time increases. It is due to that graphite particles with amorphous phase are generated on the surface due to the friction and collision of particles during pulverizing. We found that the contact electrical resistivity of graphite particles increases as the particle size decreases.

The contact electrical resistivity of graphite powders was reduced due to high molding pressure by warm press molding. This leads to improvement of the mechanical properties of graphite composite. Hydrogen gas impermeability was measured with the graphite composite, showing a possibility of the application for bipolar plate in fuel cell. And, I-V curves of the graphite composite bipolar plate exhibit a similar performance to the graphite bipolar plate.
\end{abstract}

Key words : Isotropic graphite powder, Phenolic resin, Fuel cell, Bipolar plate, Electrical conductivity

\section{1. 서 론}

최근 대표적인 화석연료인 석유가격이 폭등하면서 미래 친 환경 대체에너지원의 개발에 국제적인 초점이 맞추어져 있다. 대표적인 대체에너지원으로 연료전지가 부상 중이며 성능면에 서 일정수준에 도달한 상태로 상용화에 거의 도달하였다. 고분 자전해질 연료전지는 다른 형태의 연료전지에 비해 작동온도 가 낮고, 전류밀도 및 출력밀도가 높으며, 시동시간이 짧은 동 시에 부하변화에 대한 응답특성이 빠른 특성이 있다. 하지만 고 분자 전해질 연료전지의 상용화는 현재 $\mathrm{kW}$ 당 수천불인 스택 가격으로 어려움을 겪고 있어서 연료전지의 상용화는 어느 정 도로 생산가격을 낮출 수 있는가에 달려있다. 현재 기술로 연 료전지 스택의 가격을 부품별로 분석하면 분리판이 전체 스택 가격의 $52 \%$ 정도로 가장 높은 비중을 차지한다. 따라서 고분 자전해질 연료전지 스택의 가격을 낮추기 위해서는 분리판의 가격을 낮추는 것이 반드시 필요하다. 현재 이용되는 분리판은 대부분 고밀도 흑연을 기계 가공해 제작되는데, 가공시간이 길 어 생산성이 없고 이에 따라 제작비용이 많이 소요되고 있다.
따라서 흑연을 대체할 저가의 분리판 소재 개발이 시급하다. 분리판 소재로 이용되기 위해 요구되는 특성으로 낮은 가격 외에도 우수한 가공성, 우수한 기계적 강도와 높은 전기 전도 성, 낮은 밀도와 낮은 기계 투과율, 그리고 화학적인 안정성을 들 수 있다. 이러한 다양한 요구사항을 만족시키는 재료로 현 재 스테인레스 강을 위주로 한 금속 분리판과 흑연분말과 고 분자로 제조한 수지결합 흑연복합재 분리판 개발이 검토되고 있다. 스테인레스 강의 경우 가공성과 가격, 기계적 강도, 소 재의 전기 전도도 등은 월등히 우수하지만, 부식에 약해서 표 면에 산화막이 형성되어 전기 전도도가 급격히 감소되는 문제 점이 있다 $[1,2]$. 반면 수지결합 흑연복합재 분리판은 충진제 인 흑연분말의 전기전도도가 높고, 화학적으로 안정하고, 가볍 고, 기계적 강도가 양호하여 연료전지용 분리판으로서 적합한 물성을 나타내며, 동시에 가격이 저렴하면서 가압성형이 가능 하여 양산화가 가능하다[3]. 수지결합 흑연복합재 분리판 관련 연구는 Besmann 등은 탄소섬유복합재 분리판을 제조하여 흑 연을 대체할 수 있는 분리판 재료로서 가능성을 확인했고 일 본 Showa Denko사에서는 전기적 특성이 우수한 인조흑연분 


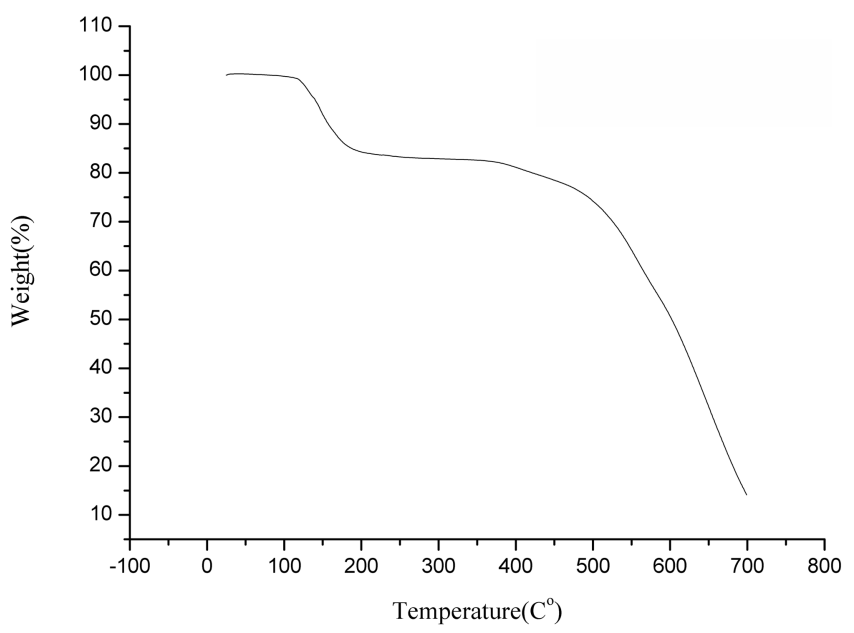

Fig. 1. Thermogravimetric curve of phenolic resin as function of temperature in air, measured with a heating rate of $10^{\circ} \mathrm{C} / \mathrm{min}$.

말을 사용하여 연료전지 분리판으로서 전기적 특성, 내구성, 경제성을 확인하였다[4]. 또한 L. L. Shaw는 CNT를 활용하여 고분자연료전지용 분리판을 제조하여 물성을 향상시키고 양산 가능성을 연구하였다 $[5,6]$.

본 연구개발에서는 상대적으로 저가인 등방성 흑연분말을 이용하여 밀도가 낮고 화학적으로 안정한 Phenolic resin을 결 합재로 사용하여 수지결합 흑연복합재를 제조하였다. Ball milling을 통해 입자크기를 제어하면서 수지결합 흑연복합재의 기계적 특성 및 전기적 특성을 평가하였다. Ball milling 공정 이 흑연입자의 크기와 표면상태에 미치는 영향을 평가하여 수 지결합 흑연복합재에서 흑연입자에 의해 전기적 특성변화를 관찰하였다. 그리고 배합비, 성형압력 등 최적의 복합화 공정 변수를 확립하여 PEM fuel cell bipolar plate용 수지결합 흑연 복합재를 제조하였다. 수지결합 흑연복합재 bipolar plate는 실 제 장착시험을 위해 유로가 새겨진 몰드에 가열가압성형(Warm press molding)으로 실형상으로 제조하여 수소불침투성, 전기 전도도, I-V곡선 등 성능평가를 실시하여 기존에 사용되는 TOYO TANSO사 등방성 흑연불럭으로 제조한 흑연재 bipolar plate와 비교하여 PEM fuel cell용 bipolar plate로의 적용 가능 성을 평가하였다.

\section{2. 실험 방법}

\section{1. 원료 및 수지결합 흑연복합재 제조}

본 연구에서는 내부식성과 전기전도도가 우수한 일본 TOYO
Table 2. Properties of phenolic resin(Resol Type)

\begin{tabular}{cccc}
\hline Items & Unit & Property & Remark \\
\hline Hardening Time & $\min$ & 14.10 & - \\
\hline Non Volatile Contents & $\%$ & 59.5 & - \\
\hline Specific Gravity & - & 1.079 & $25^{\circ} \mathrm{C}$ \\
\hline Dilution & $\%$ & 2000 & $\mathrm{Me}-\mathrm{OH}$ \\
\hline
\end{tabular}

$\mathrm{TANSO}$ 사의 등방성 흑연 $\mathrm{G} 348$ 을 전도성 충진제로 사용하였 다. 그리고 바인더는 젖음성이 좋고 접착강도가 우수한 강남화 성의 레졸타입 페놀수지 $\mathrm{KC} 4703$ 를 사용하였다. 등방성 흑연 G348과 페놀수지 KC 4703의 특성은 Table 1, 2에 나타내었다.

등방성흑연분말의 입도변화에 따른 기계적, 전기적 물성변 화를 관찰하기 위해 72시간 Ball milling을 실시하였다. 페놀 수지와 등방성흑연분말의 혼합이 용이하도록 페놀수지를 메탄 올과 부피비 10:90으로 희석하여 사용하였다. 등방성흑연분 말과 페놀수지의 혼합 시에 등방성흑연분말을 조금씩 투여하 면서 최종적으로 페놀수지와 흑연분말의 중량비가 $40: 60$, $30: 70,20: 80,10: 90$ 되도록 하였다. 혼합은 결합재인 페놀수 지가 흑연분말 입자사이에 균일하게 분포하도록 Hot-plate 위 에서 $50 \sim 100 \mathrm{rpm}$ 으로 12시간 이상 교반하였다. 교반 후 희석 제인 메탄올을 제거하기 위해 $80^{\circ} \mathrm{C}$ 로 가열하면서 다시 12 시 간 이상 교반시켜 메탄올이 완전히 제거되도록 하였다. Fig. 1 은 페놀수지의 열 중량곡선으로 $90^{\circ} \mathrm{C}$ 부근부터 알코올과 수분 이 휘발에 의한 중량감소와 $350^{\circ} \mathrm{C}$ 이상부터 급격한 중량감소 가 일어났다. $90 \sim 200^{\circ} \mathrm{C}$ 까지는 경화반응이 진행되는 구간으로 고분자인 수지가 3 차원적인 가교현상이 동반되어 기계적물성 이 향상되는 온도이다. 그리고 $200 \sim 350^{\circ} \mathrm{C}$ 까지는 방향족화합 물들이 결정화가 진행이 되다가 $350^{\circ} \mathrm{C}$ 이상에서는 산화에 의 한 분해로 무게감소가 일어났다[7]. 이러한 페놀수지의 열 중 량감소 그래프를 기반으로 메탄올이 휘발된 혼합물을 경화가 진행이 되지 않는 $80^{\circ} \mathrm{C}$ 의 건조기에 6시간 넣고 잔류한 알코 올성 용매와 저분자량의 휘발분이 제거되도록 하였다.

제조된 혼합물은 지름 $12 \mathrm{~mm}$ 원형몰드에 넣고 $10,50,100$, $150,200 \mathrm{MPa}$ 의 압력하에서 성형하였다. 이때 온도는 $180^{\circ} \mathrm{C}$ 에서 10 분간 유지하여 경화가 이루어지도록 하였다. 제조된 시 편은 완전한 경화반응이 끝나도록 $180 \sim 220^{\circ} \mathrm{C}$ 범위에서 12 시 간 유지하였다.

\section{2. 물성분석}

페놀수지의 열적거동에 대한 간접적인 자료를 얻기 위해 열 중량분석을 행하였고 사용한 기기는 스위스 Mettler사의 TGA/

Table 1. Properties of isotropic graphite

\begin{tabular}{cccccc}
\hline Grades & Specific Gravity & $\begin{array}{c}\text { Specific Resistance } \\
(\mu \Omega \cdot \mathrm{m})\end{array}$ & $\begin{array}{c}\text { Flexural Strength } \\
(\mathrm{MPa})\end{array}$ & $\begin{array}{c}\text { Shore Hardness } \\
-\end{array}$ & $\begin{array}{c}\text { Thermal Conductivity } \\
(\mathrm{W} / \mathrm{mK})\end{array}$ \\
\hline $\mathrm{G} 348$ & 1.92 & 10 & 63.7 & 68 & 128 \\
\hline
\end{tabular}




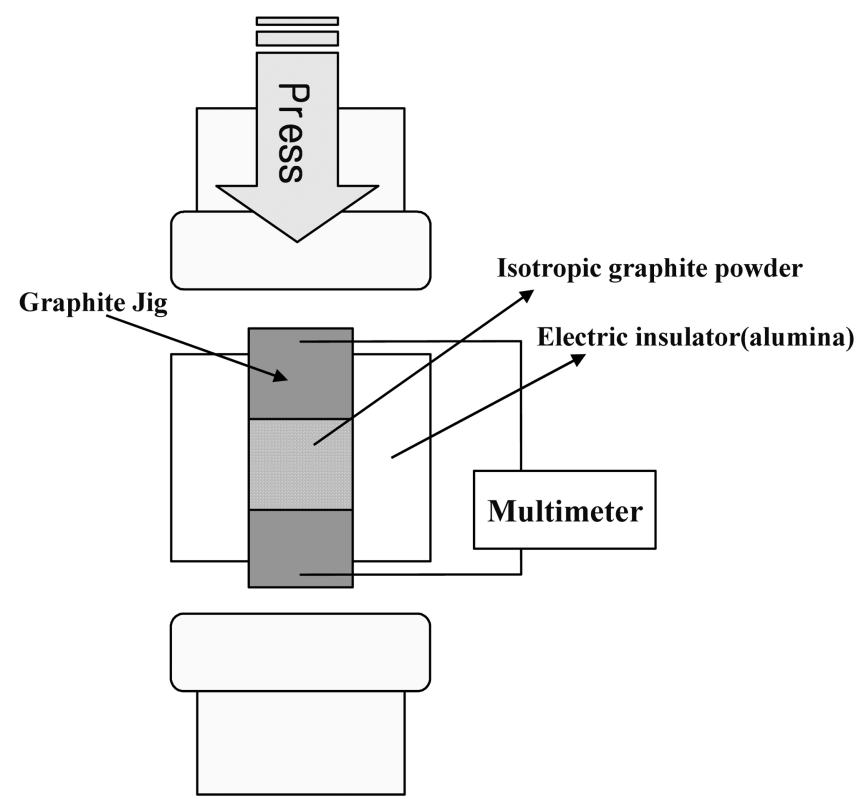

Fig. 2. Schematic diagram of specific electrical resistivity testing system for the isotropic graphite powder.

SDTA851 Thermal Analysis System이다. 분석에 사용된 시료 의 양은 약 $20 \mathrm{mg}$ 이었고, 공기 중에서 $25^{\circ} \mathrm{C}$ 부터 $700^{\circ} \mathrm{C}$ 까지 $10^{\circ} \mathrm{C} / \mathrm{min}$ 의 속도로 승온 하였다. 분쇄조건을 달리하여 제조한 흑연분말의 입도는 MELVERN사 MASTERSIZER를 이용하 여 측정하였고 형상 등 미세구조는 주사전자현미경(SEM, TAPCON사 SM300)으로 관찰하였다. 분쇄방법에 따른 표면결 합 상태변화는 프랑스 Jobin-Yvon사 LabRam HR (High Resolution)를 사용하여 D-peak (disorder peak) $1350 \mathrm{~cm}^{-1}$ 과 흑 연피크인 G-peak (graphite peak) $1590 \mathrm{~cm}^{-1}$ 를 관찰하였다. 그 리고 분쇄 후 흑연분말의 흑연화도 변화가 있는지 측정하기 위해 XRD 분석을 통해 식 (1)과 같이 002면간거리를 구하여 계산하였다.

$$
\mathrm{G}(\text { 흑연화도 })=\left[3.44-\mathrm{d}_{(002)}\right] /[3.44-3.354]
$$

여기에서 $\mathrm{d}_{(002)}=\lambda /(2 \sin \theta), \mathrm{d}$ : interlayer spacing,

$\theta$ :Bragg's angle, $\lambda$ : Wavelength of $\mathrm{Cu}$ Ka X-ray $(1.5406 \AA)$

또한 등방성흑연분말의 입자간 접촉저항변화를 관찰하기 위 해 Fig. 2와 같이 milliohmic multimeter를 사용하여 등방흑연 분말의 양과 가압하중을 달리하면서 양끝단의 저항을 측정하 여 비저항을 측정하였다. 최종 제작된 복합재의 표면전기저항 및 전기전도도 측정은 Changmin Tech사 Sheet Resist Tester (SR 3000)를 이용하여 4 probe method로 측정하였다. 조건별 로 제조한 복합재의 굴곡강도는 KS L 1591 방법으로 만능시 험기(Model 4202, Instron JAPAN)를 사용하여 $500 \mathrm{~kg}$ load cell, cross head speed $0.5 \mathrm{~mm} / \mathrm{min}$ 의 조건하에서 측정하였다. 수지결합 흑연복합재의 밀도와 흡수율은 KS L 3114에 의거 하여 소수점 넷째 자리 화학저울(AT201, METTLER, Switzerland)을 사용하여 측정하였다. 최종 제조된 수지결합 흑연복합
재의 표면상태 및 흑연분말의 분포상태는 전도성 충진제의 편 광성을 이용하여 미국 OLYMPUS사 OLYMPUS BX51 Optical microscope를 사용하여 관찰하였다. 또한 수지결합 흑연복합재 의 수소기체 불침투성은 PMI사 Capillary Flow Porometer (Model CFP-1500AELT)로 측정하였고 측정가스압력은 상압에 서 $5.5 \mathrm{~atm}$ 까지 순차적으로 압력을 증가시키면서 측정하였다.

I-V곡선은 LG Micron사 PEM Fuel cell test station을 사용 하여 단전지 시험을 실시하였다. 시험조건은 실온 가습 조건

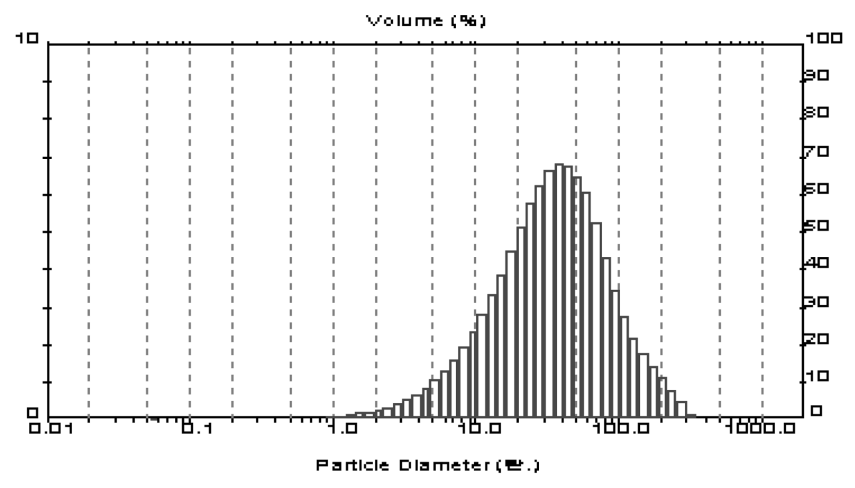

mean diameter : 49.75 $\mu \mathrm{m}$ ( ball mill 0Hr. )

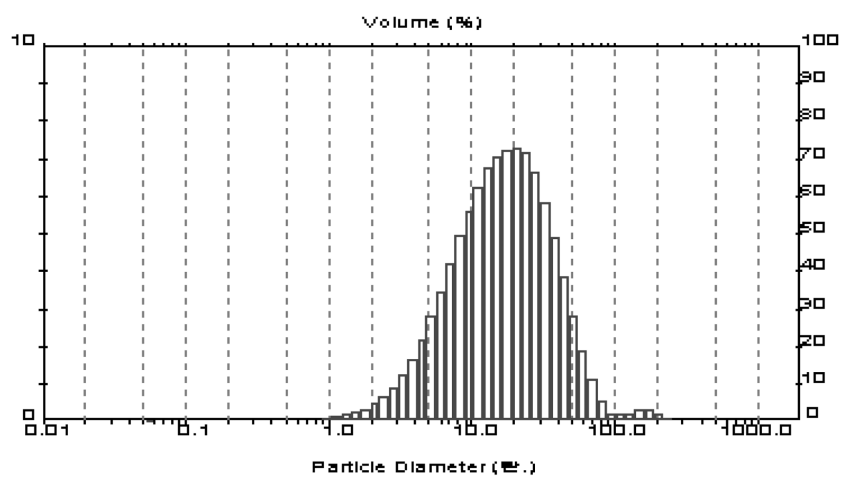

mean diameter : $22.80 \mu \mathrm{m}$ ( $24 \mathrm{Hr}$.

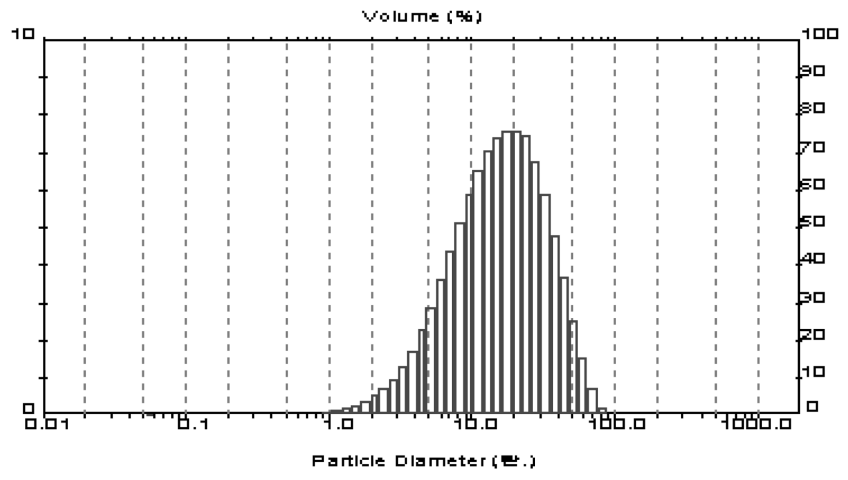

mean diameter : 19.77 $\mu$ m ( 72Hr. )

Fig. 3. Particle diameters of isotropic graphite powder as a function of ball milling time. 


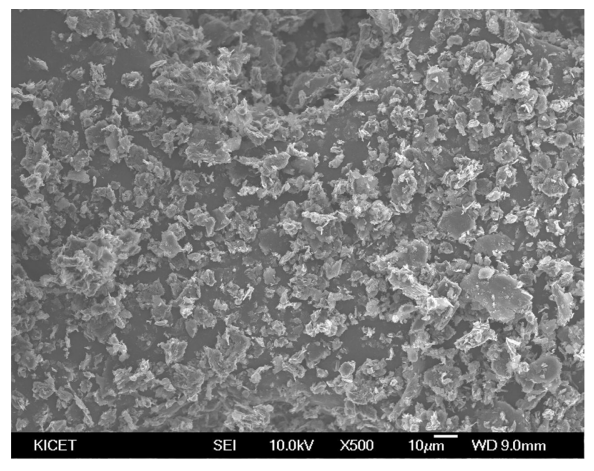

(X 500)

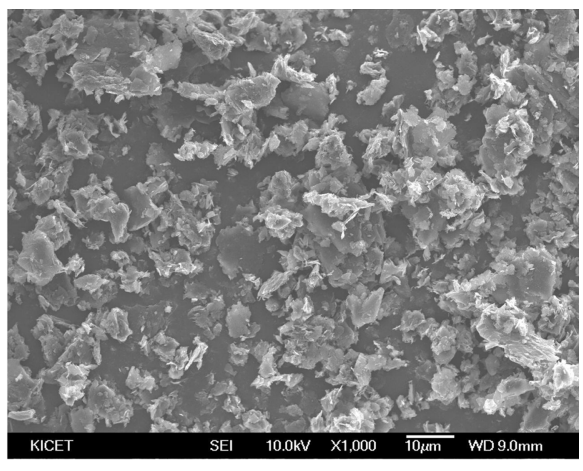

(X 1000)

Fig. 4. SEM image of isotropic graphite powder after ball milling.

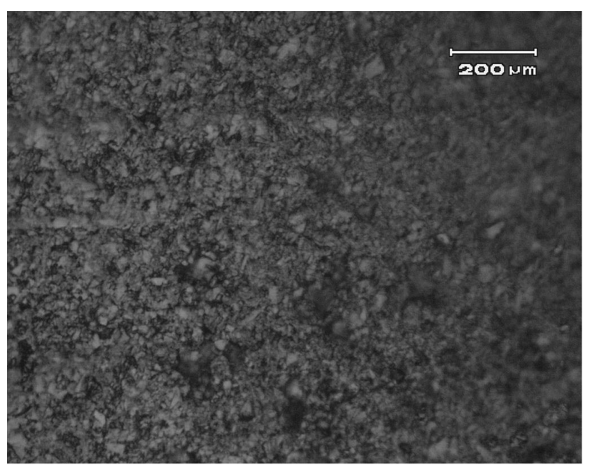

(ball milling time-0Hr., $49.75 \mu \mathrm{m}$ )

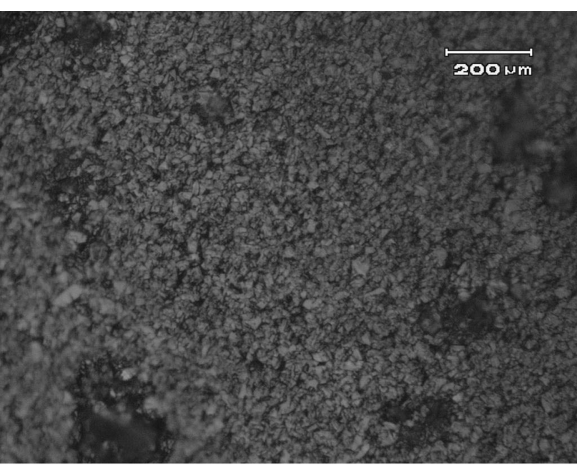

(ball milling time-72Hr., $19.77 \mu \mathrm{m}$ )

Fig. 5. Polarizing microscope images of resin bonded graphite composite as a function of ball milling time.

하에서 $\operatorname{anode}\left(\mathrm{H}_{2}\right)$ 를 흐름속도 $209 \mathrm{ml} / \mathrm{min}$ 로 주입했고 cathode (Air)는 흐름속도 $630 \mathrm{ml} / \mathrm{min}$ 로 주입하면서 실시하였다.

\section{3. 결과 및 고찰}

\section{1. 흑연분말의 분쇄와 전기적 특성}

전도성 충진제인 등방성흑연분말 입자간 최밀 충진을 이루 어 수지결합 흑연복합재의 전기적, 기계적 특성을 향상시키고 자 Ball milling을 통해 입자의 크기, 형상을 작고 균일하게 입 도를 조절하였다. Fig. 3은 Ball milling 시간에 따른 등방성흑 연분말의 입도변화를 나타내었다. Ball milling시간 24시간 후 분말의 평균입경은 $22.9 \mu \mathrm{m}$ 이고 72 시간의 평균입경은 19.77 $\mu \mathrm{m}$ 로 작아졌다. 그리고 흑연분말의 입경분포 또한 Ball milling 시간이 길어짐에 따라 분포범위가 좁아졌다. Fig. 4은 72시간 Ball milling 후의 흑연분말의 전자현미경 사진이다. 입자들이 전반적으로 작고 균일하게 분포되어 있다. 그리고 입자들은 분 쇄가 진행이 되면서 입경이 작아졌지만 판상의 흑연결정 특성 상 작은 크기의 판상형상으로 분쇄되었다. 전도성 충진제인 흑 연의 편광성을 이용하여 입자간 분포 및 응집상태를 편광현미
경을 이용하여 관찰하였으며 결과는 Fig. 5와 같다.

수지결합 흑연복합재 시험편은 Ball milling을 통해 분쇄된 등방성흑연분말과 분쇄 전 등방성흑연분말을 수지와 흑연분말 을 $2: 8$ 로 각각 배합하여 제조하여 관찰하였다. 분쇄 전 흑연

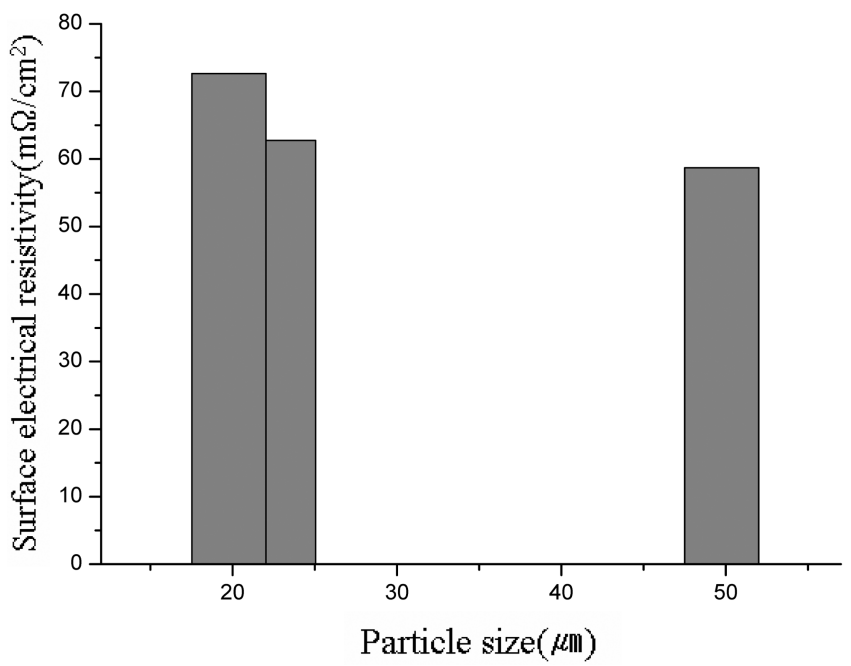

Fig. 6. Surface electrical resistivity of resin bonded graphite composite as a function of particle size $(\mu \mathrm{m})$. 
분말을 사용한 복합재의 경우 상대적으로 분포가 불균일하고 응집되는 현상이 보였고, Ball milling 72 시간 분쇄 후 흑연분 말을 사용한 복합재의 경우 분포가 상대적으로 균일해졌고 입 자들간의 응집현상도 개선이 되었다. Ball milling 분쇄에 따 른 전기적 특성을 평가하기 위해 복합재의 표면전기저항을 측 정하였다. Ball milling 분쇄가 진행이 되면서 입자가 작고 균
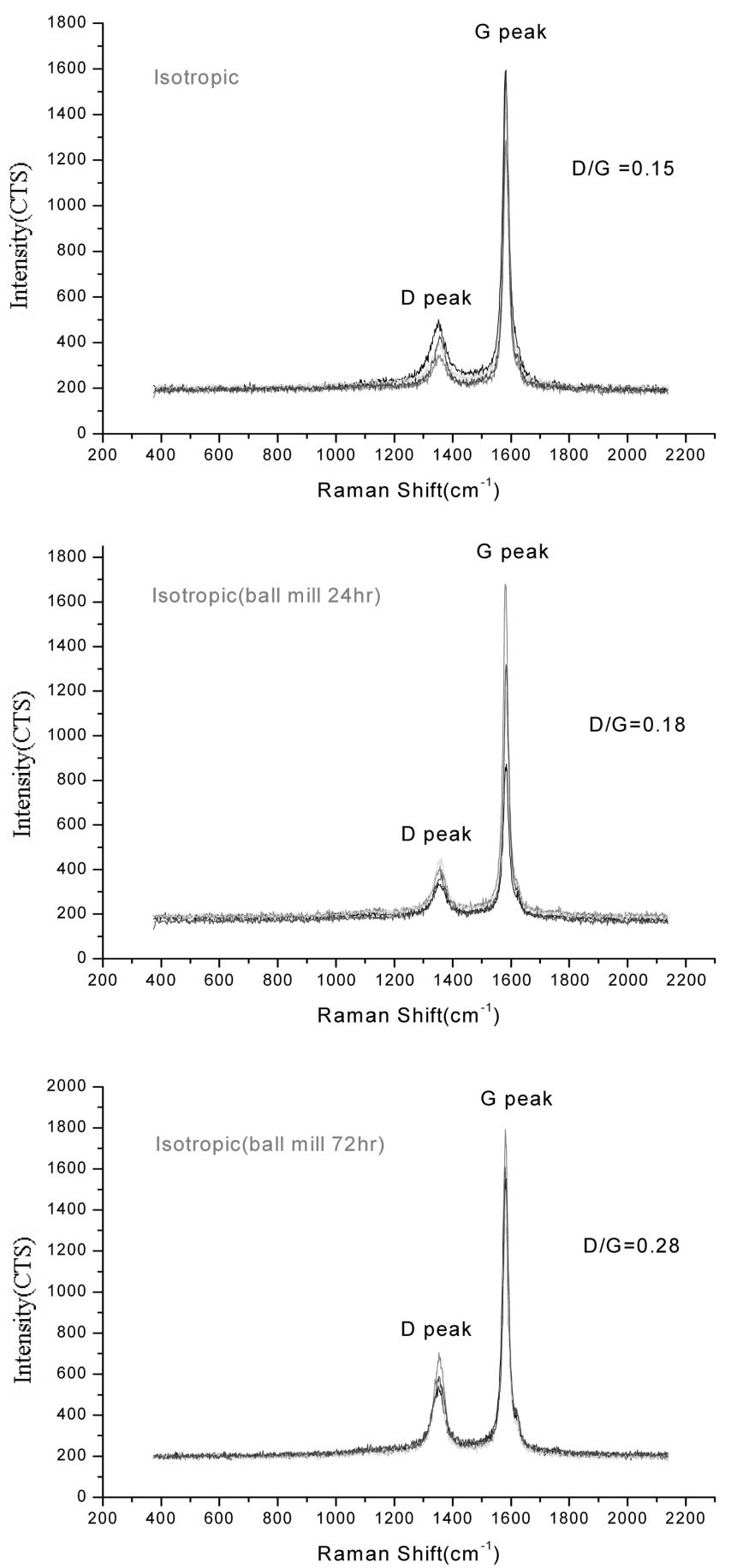

Fig. 7. Raman curves of isotropic graphite powder as a function of ball milling time.
일해져서 입자간의 접촉이 최대가 되어 전기전도성이 향상될 것으로 기대하였다. 그러나 Fig. 6의 복합재 표면전기저항 측정 값을 보면 분쇄하지 않은 흑연분말을 사용한 복합재의 표면전 기저항은 $28.2 \mathrm{~m} \Omega / \mathrm{cm}^{2}$ 이었고 24 시간, 72 시간 분쇄한 흑연분말 을 사용한 복합재의 표면전기저항은 각각 $33.95,35.56 \mathrm{~m} \Omega / \mathrm{cm}^{2}$ 을 나타내어 오히려 Ball milling 분쇄시간을 길게 하여 입자가 작고 균일한 입경을 갖는 흑연분말을 사용한 수지결합 흑연복
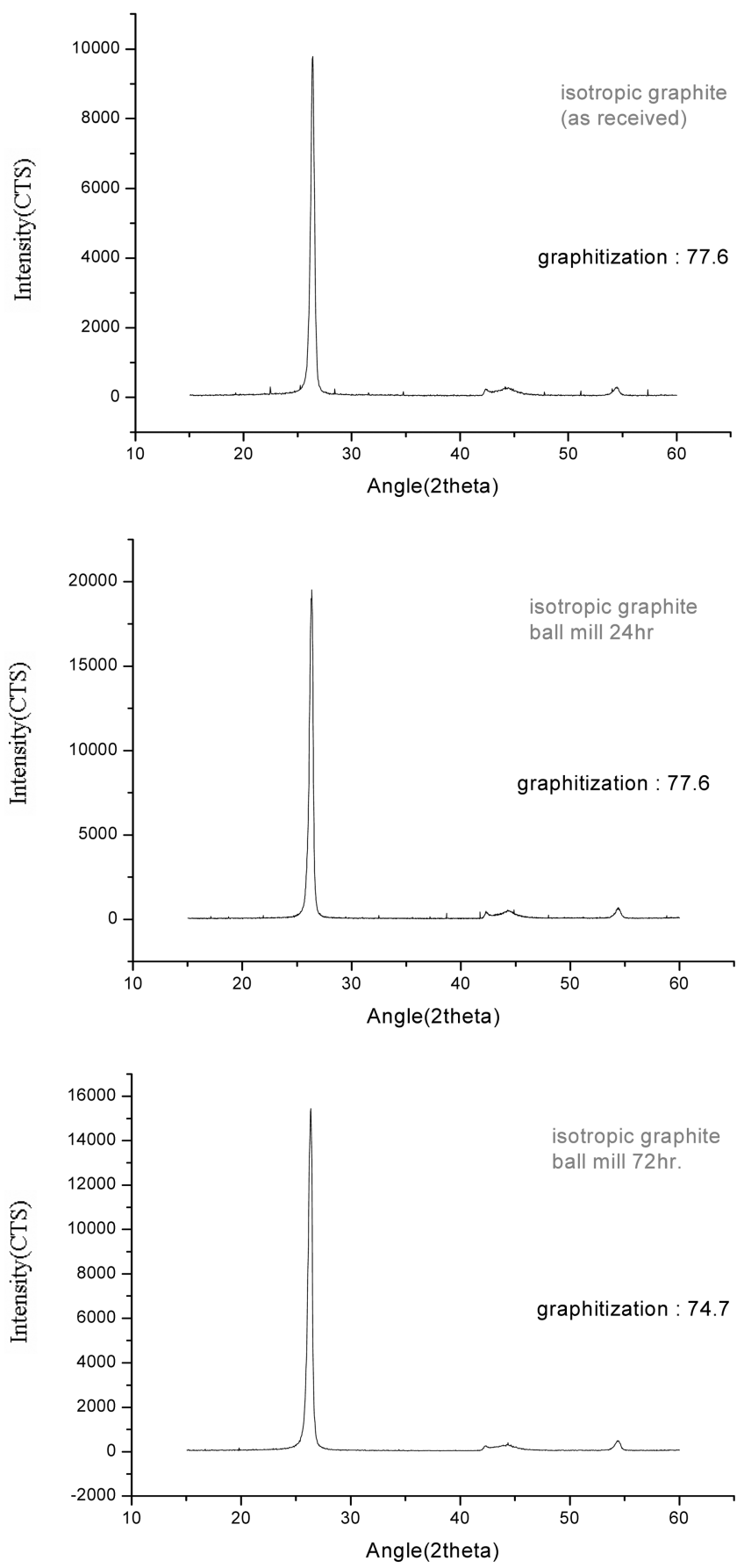

Fig. 8. XRD curves of isotropic graphite powder as a function of ball milling time. 
합재의 표면전기저항이 높아지는 경향을 보이고 있다.

Fig. 7 는 분쇄에 의한 흑연분말의 표면결합상태를 확인하기 위 해 측정한 Raman 결과이다. 분쇄가 진행이 되면서 $1350 \mathrm{~cm}^{-1}$ 부근의 disorder peak의 세기가 커지고 $1590 \mathrm{~cm}^{-1}$ 부근의 graphite peak의 세기가 작아져 $\mathrm{D} / \mathrm{G}$ 비가 커지고 있음을 관찰 할 수 있다. 이는 분쇄가 진행되면서 분쇄 media 또는 입자들 상호간에 충돌 및 마찰에 의해 흑연입자가 손상을 입어 결정 상태가 무정형으로 바뀐 것으로 판단이 된다.

Fig. 8은 Ball milling분쇄에 의해 흑연입자들의 결정상태를 관찰하고자 $\mathrm{XRD}$ 를 측정한 결과이다. $\mathrm{d}(002)$ 값을 구하여 계산 한 흑연화도는 Ball milling 시간과 상관없이 평균 74.7 77.6 을 나타내어 흑연화도의 변화가 일어나지는 않았다. 이러한 결 과는 분쇄가 진행되면서 무정형의 정도가 커지는 Raman 분석 결과와는 상반되는 것인데 이는 $\mathrm{XRD}$ 분석의 특성상 흑연분말 내에 조사되는 $\mathrm{X}$ 선의 세기는 재료의 밀도와 침투깊이에 비례 한다는 $\mathrm{I}_{\mathrm{x}}=\mathrm{I}_{\mathrm{o}} \mathrm{e}^{-(\mu / \rho) \mathrm{x}}$ 에 의거하여 XRD 타겟 $\mathrm{Cu}(\mathrm{ka})$ 의 흑연 질 량흡수계수 4.219 를 적용하여 X선의 흑연입자 내 침투깊이를 계산하면 최소 $1 \mu \mathrm{m}$ 이상이어서 흑연화도가 변함이 없다는 것 은 입자내부에는 $\mathrm{d}(002)$ 값의 변화 즉, 결정성 변화가 없이 흑 연입자 표면에 집중해서 무정형화 된다는 의미가 된다. 이는 Ball milling시 분쇄 media와 입자간의 충돌 및 마찰에 의해 흑 연표면이 손상을 받기 때문으로 판단된다. 따라서 전기전도성 은 주로 표면접촉상태에 결정이 되는데 분쇄시간이 길어지면 흑연표면이 손상되어 무정형화 되면서 입자가 작아져 입자간 접촉저항이 높아지고 결국, 수지결합 흑연복합재의 표면전기 저항이 높아진 것으로 판단된다.

Fig. 9는 흑연입자 간 접촉량과 접촉상태가 전기비저항에 미 치는 영향을 측정하고자 전기절연체 몰드에 수지결합재를 배 제한 상태에서 흑연분말만을 넣고 일정압력으로 고정한 후에 전기비저항을 측정하였다. 흑연 분말량을 늘려가면서 측정한 결과 흑연 분말량이 증가할 수 록 전기비저항이 증가하였다.

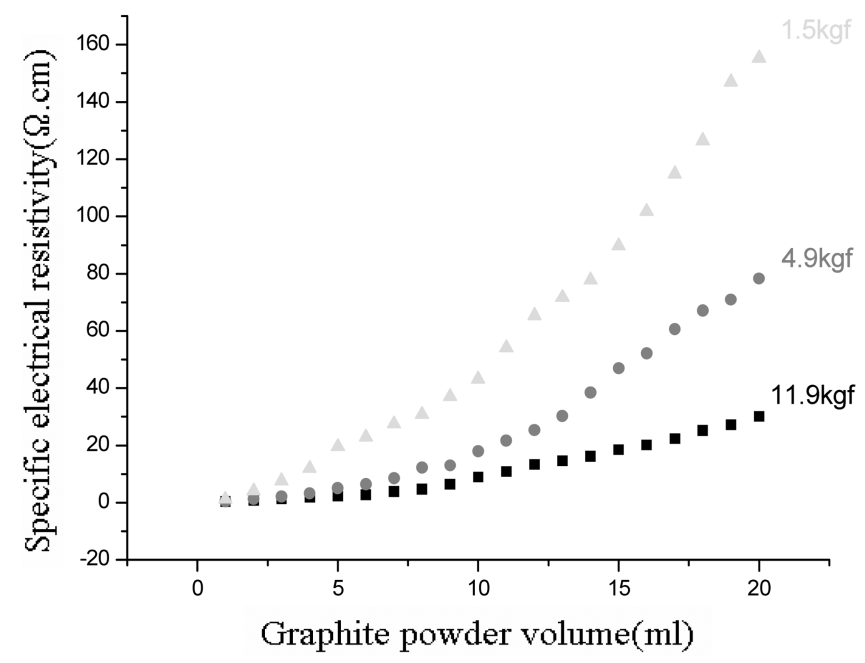

Fig. 9. Specific electric resistance of graphite powder as a function of volume.

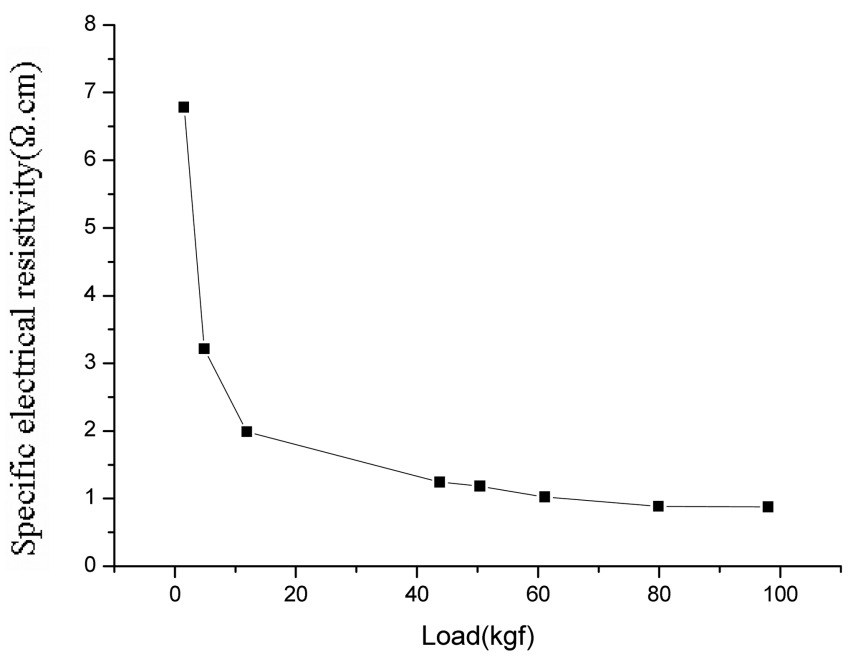

Fig. 10. Specific electrical resistivity of graphite powder as a function of $\operatorname{load}\left(\mathrm{kg}_{\mathrm{f}}\right)$.

이는 수지결합 흑연복합재의 전기저항은 입자의 특성에 영향 을 받는데 입자들은 상호접촉상태에 의해 전기적 특성 즉, 전 기전도도가 결정이 된다. 그런데 기본적으로 입자들 간에는 접 촉에 의한 접촉저항이 있고 이는 접촉되는 횟수가 많아지면 이에 비례하여 전기저항이 높아지게 된다. 따라서 흑연분말 량 이 많아지면 접촉되는 횟수가 많아져 사용되는 흑연분말 량에 비례하여 전기비저항이 높아진 것으로 판단된다. 즉, 전기비저 항은 접촉저항이 일어나는 흑연입자의 접촉횟수에 비례하여 높아지는 것으로 판단되며 분쇄에 의해 흑연입자의 크기가 작 아지면 접촉회수가 증가하므로 부피 전체의 접촉저항이 높아 져 비저항이 높아지는 것으로 판단된다. 흑연 분말간 접촉 시 접촉압력을 변화시켜가면서 전기 비저항값 변화를 Fig. 10에 나타내었다. 접촉압력이 증가할 수 록 전기 비저항값은 낮아 졌다. 이는 접촉압력이 높아지면 입자간 접촉저항을 감소시켜

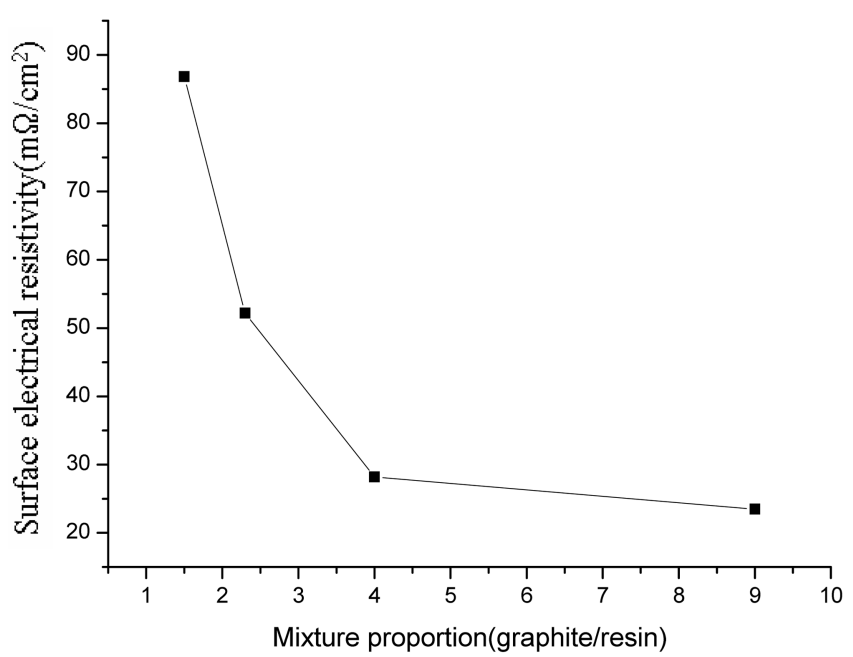

Fig. 11. Surface electrical resistivity of resin bonded graphite composite as a function of mixture proportion. 


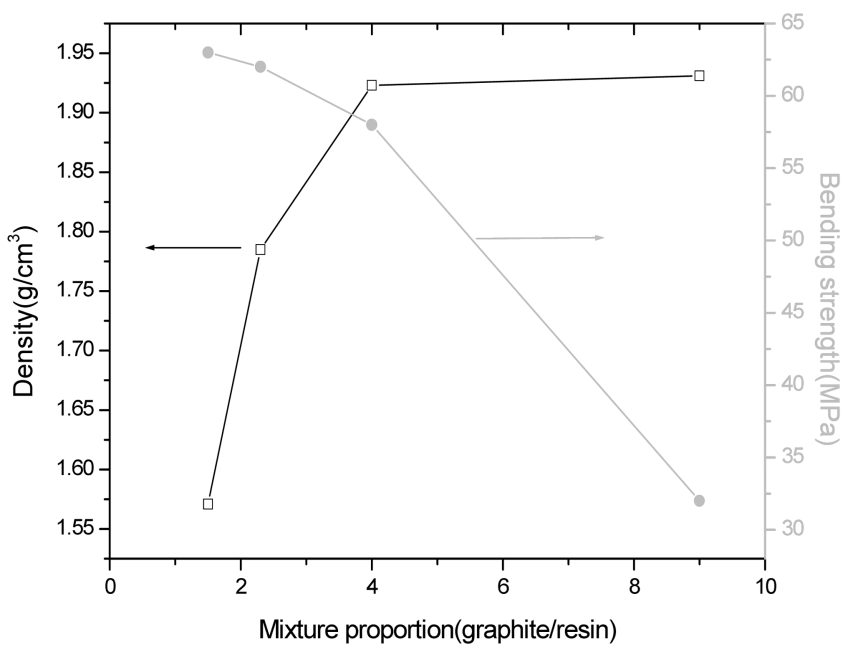

Fig. 12. Density and bending Strength of resin bonded graphite composite as a function of mixture proportion.

궁극적으로는 수지결합 흑연복합재의 전기비저항을 낮추는 것 으로 판단된다. 그러나 압력이 높아짐에 따라 비저항값의 감 소폭이 완만해지는 것은 입자간 접촉상태가 좋아지면서 전자 의 흐름이 원활해져 전기저항이 낮아졌지만 입자들 자체의 결 정 끝 부근에서의 저항 감소에는 한계가 있어서 영향을 미치 지 못한 것으로 판단된다.

\section{2. 수지결합 흑연복합재의 기계적, 전기적 특성}

Fig. 11은 흑연과 수지의 배합비에 따른 표면전기저항값의 변화를 나타내었다. 흑연입자량이 증가할 수 록 표면전기저항 값은 감소하였다. 이는 앞서 언급한 바와 같이 흑연의 충진분 율이 증가하면서 표면전기저항이 감소하지만 흑연입자 자체의 접촉저항으로 일정한 값 이하로는 감소하지 않았다. 또한 흑 연 충진분율에 따른 밀도와 굴곡강도 변화를 나타낸 Fig. 12 에서 흑연의 충진량이 증가하면서 밀도는 증가하였지만 흑연 1수지량이 커지면서 결합재인 수지가 상대적으로 작아지면서 결합강도가 약해져 굴곡강도는 감소하였다.

Figs. 13과 14은 성형압에 따른 표면전기저항값, 밀도, 굴곡 강도값 변화를 나타내었다. 성형압력이 증가할수록 흑연입자 간의 접촉강도가 증가하면서 표면전기저항값이 낮아졌다. 그 리고 밀도값, 굴곡강도도 증가하였다. 하지만 굴곡강도의 경우 $200 \mathrm{MPa}$ 의 성형압력에서 소폭의 감소가 일어났는데 이는 $180^{\circ} \mathrm{C}$ 에서 경화반응이 진행이 되면서 발생하는 휘발분이 높 은 성형압력에 의해 수지결합 흑연복합재 내부에 갇혀서 응력 층이 발생하여 엉성한 조직이 되면서 굴곡강도값이 감소한 것 으로 판단된다.

Fig. 15 는 최종 제작된 수지결합 흑연복합재를 $100 \times 100 \times 2$ 규격으로 시험편을 가공하고 수소가스 불침투성을 측정결과이 다. 수소가스압 $5 \mathrm{~atm}$ 까지 $0.5 \mathrm{~atm} / \mathrm{min}$ 으로 가스압력을 상승시 키면서 측정하였다. 초기에는 투과되는 가스량이 $95 \mathrm{cc} / \mathrm{min}$ 이

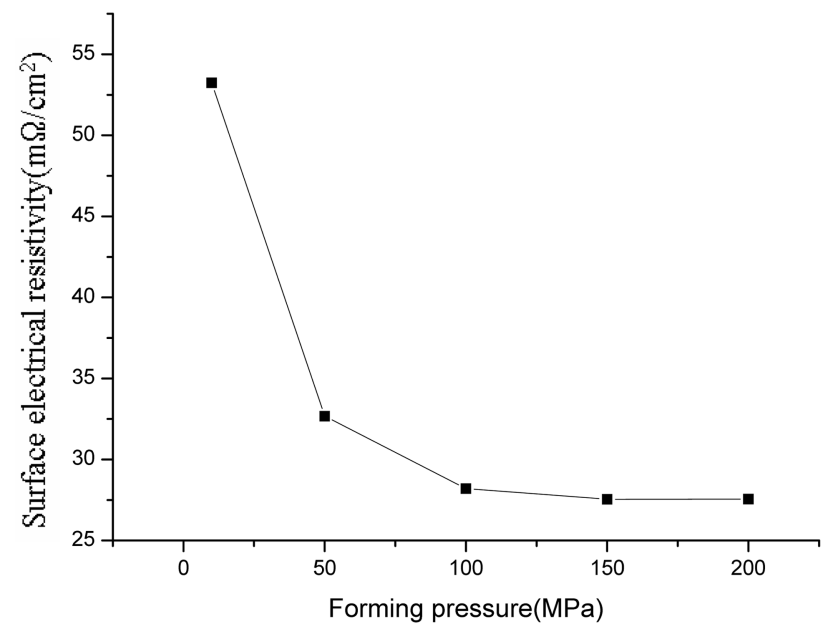

Fig. 13. Surface electrical resistivity of resin bonded graphite composite as a function of forming pressure.

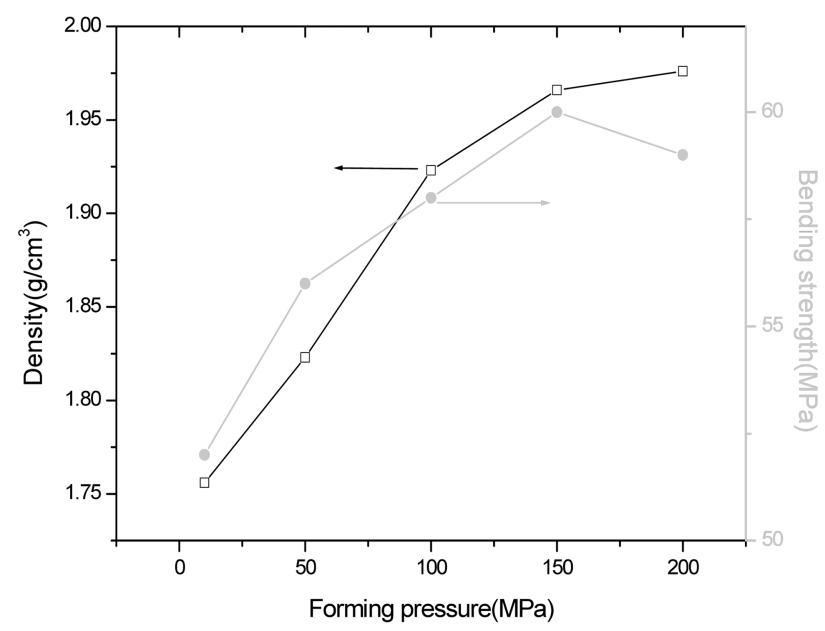

Fig. 14. Density and Bending Strength of resin bonded graphite composite as a function of forming pressure.

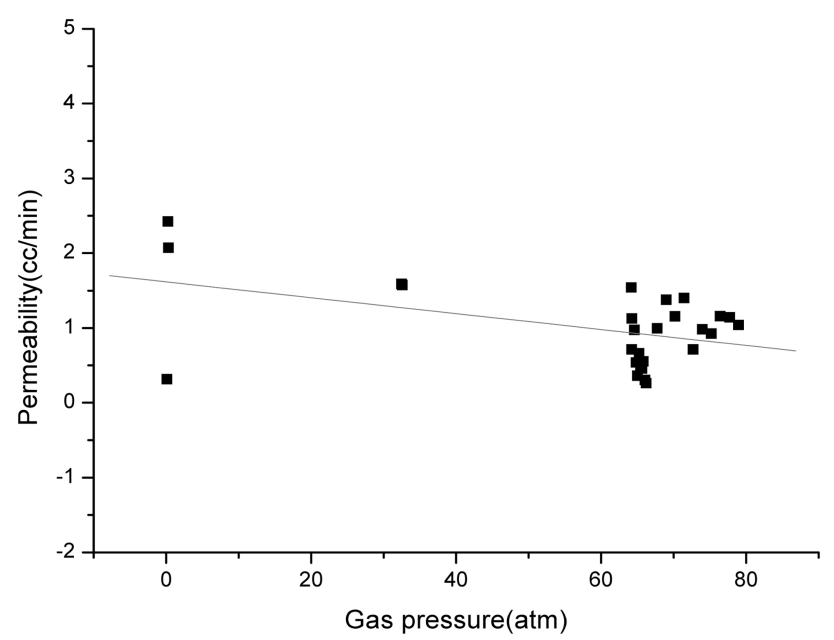

Fig. 15. Permeability of resin bonded graphite composite as a function of gas pressure. 


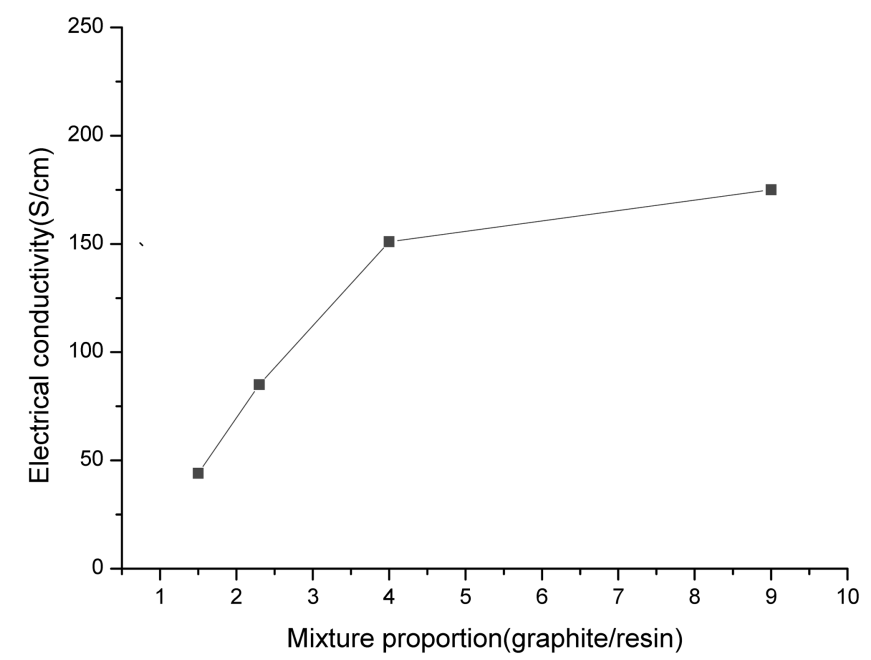

Fig. 16. Electrical conductivity of resin bonded graphite composites as a function of mixture proportion.

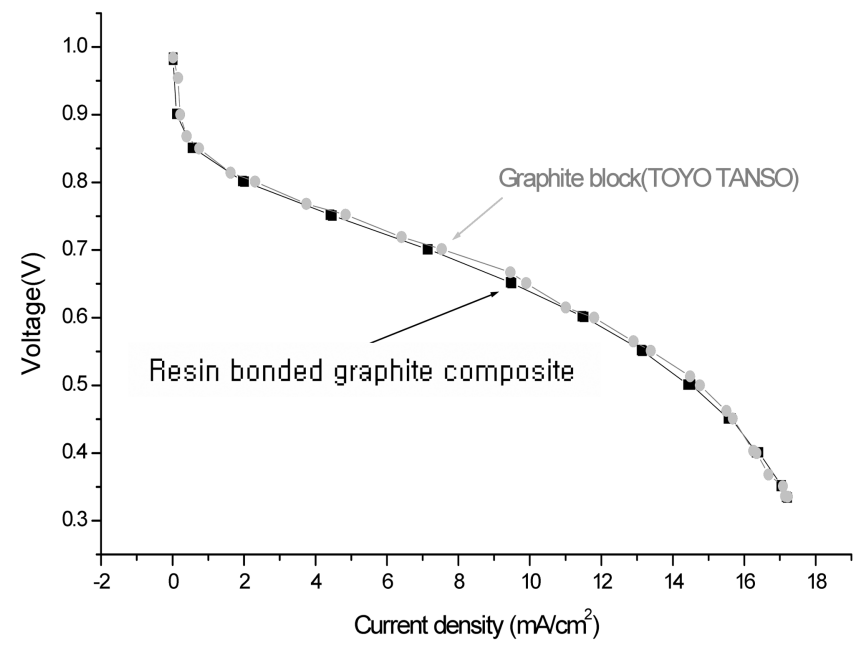

Fig. 17. I-V curves of resin bonded graphite composite bipolar plate for PEM fuel cell.

었고 가스압이 증가하여 $5 \mathrm{~atm}$ 에서는 $51 \mathrm{cc} / \mathrm{min}$ 로 낮아졌다. 일반적으로 가스압력이 높아지면 투과율이 높아지는 것이 보 통이나 수지결합 흑연복합재의 탄성이 낮아 가스압이 증가하 면 눌림 현상이 발생하여 수지결합 흑연복합재의 밀도가 높아 져 가스투과율 오히려 낮아지는 것으로 판단된다.

Fig. 16은 4point probe method로 수지결합 흑연복합재의 전 기전도도를 측정한 결과이다. 흑연의 함량이 증가할 수 록 전 기전도도는 향상되었고 수지:흑연 $\mathrm{wt} \%$ 비율이 $1: 9$ 에서 전기전 도도값이 최고를 나타내었으나 강도값이 $33 \mathrm{MPa}$ 로 취급이 어 려울 정도로 기계적강도가 낮아 의미가 없었다. 수지 : 흑연 $\mathrm{wt} \%$ 비율 $2: 8$ 에서 $151 \mathrm{~S} / \mathrm{cm}$ 을 나타내 PEM fuel cell에 적합한 전기전도도를 나타내고 기계적강도도 $57 \mathrm{MPa}$ 이상의 값을 나 타내 최적의 배합비임을 확인하였다. 그림 17은 단지전지 형 식으로 PEM fuel cell test station을 구성하여 유로가 새겨진 몰드를 이용하여 가열가압성형으로 net-shape으로 제조한
$100 \times 100 \times 2$ 규격의 수지결합 흑연복합재 연료전지 분리판의 $\mathrm{I}-\mathrm{V}$ 성능을 시험한 결과이다. 비교 시험으로 기존에 사용하는 TOYO TANSO사 등방성 흑연블럭 G458재질로 제조된 흑연 분리판의 $\mathrm{I}-\mathrm{V}$ 값을 측정하였다. GDL은 $3 \mathrm{M}$ 사의 anode/cathode type-I 3M 2950위에 Pt loading 양이 $0.4 \mathrm{mg} / \mathrm{cm}^{2}$ 인 $3 \mathrm{M}$ 사의 7-layer 및 teflon gasket을 사용하였으며. $100 \%$ R.H, 흐름속도 는 anode $\left(\mathrm{H}_{2}\right) 209 \mathrm{ml} / \mathrm{min}$, cathode(Air) $630 \mathrm{ml} / \mathrm{min}$ 로 유량을 주며 실온에서 실시하였다. 이때 MEA의 activation을 위해 24 시간 노화를 실시한 후 성능시험을 진행하였다. 비교적으로 분 리판의 전기전도도의 차이를 보였지만 위의 실험 조건에서는 $\mathrm{OCV}$ 및 Current density 등에서 기존의 흑연분리판과 비교적 동일 성능을 보이고 있다.

\section{4.}

Ball milling시간이 길어짐에 따라 흑연분말 입자크기가 작 아지고 분포범위가 좁아졌다. 그리고 입자들은 작은 크기의 판 상형상을 하고 있음을 확인하였다. 분쇄 전 흑연분말 사용 수 지결합 흑연복합재의 경우 분포가 불균일하고 응집되는 현상 이 보였으나 분쇄 후 흑연분말을 사용한 수지결합 흑연복합재 의 경우 분포가 상대적으로 균일해졌고 입자들 간의 응집현상 도 상당히 개선이 되었다. 하지만 분쇄한 흑연분말을 사용한 수지결합 흑연복합재의 표면전기저항은 오히려 높아졌다. 이 는 분쇄가 진행이 되면서 분쇄 media 또는 흑연입자들 상호간 에 충돌 및 마찰에 의해 흑연입자 표면결합이 손상을 입어 무 정형으로 바뀐 것에서 원인을 찾을 수 있으며 또한 분쇄에 의 해 입자가 작아져 흑연입자 간 접촉되는 횟수가 많아져 접촉 전기저항이 높아져 수지결합 흑연복합재의 전기저항이 높아진 것으로 판단된다. 이를 해소하기 위해서는 흑연분말 접촉압력 에 따른 전기비저항값 변화에서 보듯이 접촉압력을 높여 입자 간 접촉전기저항을 감소시켜 수지결합 흑연복합재의 전기비저 항을 낮추어야 한다. 하지만 흑연입자 자체의 접촉저항으로 일 정한 값 이하로는 감소되지 않는 한계를 보이고 있다.

흑연분률이 증가하면서 흑연입자간의 접촉이 양호해져 표면 전기저항이 감소하지만 흑연입자 자체의 접촉전기저항으로 일 정한 값 이하로는 감소하지 않았다. 또한 흑연분률이 증가하면 서 밀도값이 증가하였지만 접착력을 담당하는 바인더인 수지 량이 상대적으로 작아지면서 굴곡강도값은 감소하였다. 성형압 력이 증가할수록 흑연입자간의 접촉상태가 양호해지면서 표면 전기저항값이 낮아졌다. 그리고 성형압력에 비례하여 밀도값, 굴곡강도도 증가하였다. 하지만 과도한 성형압력은 경화시 발 생하는 휘발분으로 인해 굴곡강도값이 감소하는 현상을 보였다. 수지결합 흑연복합재의 가스불침투시험 결과, 낮은 가스압 에서는 투과되는 가스량이 $95 \mathrm{cc} / \mathrm{min}$ 이었고 가스압이 증가하 여 $5 \mathrm{~atm}$ 에서는 $51 \mathrm{cc} / \mathrm{min}$ 로 낮아졌다. 이는 수지결합 흑연복 합재의 탄성이 낮아 가스압이 증가하면 눌림 현상이 발생하여 가스투과율이 오히려 낮아지는 것으로 판단된다. 수지 : 흑연 
$\mathrm{wt} \%$ 비율 $2: 8$ 에서 $151 \mathrm{~S} / \mathrm{cm}$ 을 나타내고 기계적강도도 $57 \mathrm{MPa}$ 이상의 값을 나타내 연료전지용 bipolar plate 소재로서 최적의 배합비임을 확인하였다. 유로가 새겨진 $100 \times 100 \times 2$ 규격의 수지결합 흑연복합재 연료전지용 bipolar plate의 I-V 성능을 시험한 결과, 기존의 TOYO TANSO사 G458 재질의 흑연 bipolar plate와 비교해서 OCV 및 Current density 등에서 비교 적 동일 성능을 보이고 있다.

\section{REFERENCES}

[1] Wind, R. S.; Kaiser, W.; Bohm, G. J. Power Sources 2002,
$105,256$.

[2] Kumar, A. ; Reddy, R. G. J. Power Sources 2004, 129, 62.

[3] Lee, H.-S.; Ahn, S.-H.; Jun, E.-S.; Ahn. B.-K. Transaction of KSAE 2006, 14, 39.

[4] Besmann, T. M.; Klett, J. W.; Henry, J. J.; Edgar, L. C. J. The Electrochemical Society 2006, 30, 39.

[5] $\mathrm{Wu}, \mathrm{M}$; Shaw, L. L. International Journal of Hydrogen Energy 2005, 30, 373

[6] Joo, W.-K.; Song, J.-G.; Choi, H.-S. Transaction of KSAE06-S0289 2006, 1804

[7] Cho, D.-H.; Ahn, Y.-S.; Lee, S.-C.; Yoon, K.-H. Korean Journal of Materials Research 1997, 7, 838 